\title{
ANALISIS MOTIVASI BELAJAR SISWA DALAM PEMBELAJARAN MENGGUNAKAN MEDIA GOOGLE CLASSROOM
}

\author{
Herziza Susana $^{1)}$, Mar'atul Afidah ${ }^{2)}$, Sri Wahyuni ${ }^{3)}$, Al Khudri Sembiring ${ }^{4)}$ \\ ${ }^{1), 2), 3), 4)}$ Program Studi Pendidikan Biologi, Universitas Lancang Kuning \\ Email ${ }^{1)}$ :herzizasusana96@gmail.com \\ Email $^{2)}$ :maratul@unilak.ac.id \\ Email $^{3)}$ : sriwahyunifkip@unilak.ac.id \\ Email $^{4)}$ :alkhudri_s@unilak.ac.id
}

\begin{abstract}
ABSTRAK: Motivasi belajar adalah dorongan yang menggerakan, mengarahkan, dan mempertahankan perilaku siswa dalam kegiatan belajar, maka motivasi sebagai keseluruhan daya penggerak di dalam diri siswa yang menimbulkan kegiatan belajar. motivasi belajar siswa yang rendah hal itu ditandai penyelesaian tugas dari guru yang ditunda-tunda selain itu siswa lebih senang dengan tugastugas yang sederhana, sedangkan motivasi siswa yang tinggi apabila siswa tekun menghadapi tugas. Penelitian ini bertujuan untuk mengetahui motivasi belajar dalam pembelajaran menggunakan media Google Classroom. Penelitian ini merupakan penelitian deskriptif dengan metode survei. Subjek penelitian siswa kelas X MIA MAN 4 Pekanbaru. Instrument penelitian berupa angket skala motivasi belajar siswa yang terdiri dari 30 pernyataan yang terdapat 13 pernyataan positif dan 17 pernyataan negatif. Teknik pengumpulan data dalam penelitian ini menggunakan angket dan dokumentasi. Teknis Analisis data yang digunakan pada penelitian ini adalah statistik deskriptif dengan bantuan excel 2016. Hasil penelitian menunjukkan rerata skor 2,71 (67,93\%) dengan kategori tinggi. Dari hasil penelitian ini menunjukkan bahwa motivasi belajar siswa pada kelas X MIA MAN 4 Pekanbaru menggunakan media Google Classroom dengan kategori tinggi.
\end{abstract}

\section{Kata Kunci: Pembelajaran, Motivasi Belajar, Google Classroom}

ABSTRACT: Learning motivation is the motivating factor that moves, directs, and maintains student behavior in learning activities, thus motivating students as the driving force behind learning activities. Low student motivation is indicated by the performance of work by the teacher who has been delayed. In contrast, students prefer easy activities, while student motivation is high when students are diligent in encountering up to the task. The objectives of this research is to identify learning motivation in learning using the Google Classroom media. This research is a descriptive study using a survey method. The subjects of research were class X MIA MAN 4 Pekanbaru. The research instrument took the form of a questionnaire on student motivation, consisting of 30 statements containing 13 positive statements and 17 negative statements. The data collection techniques used in this study were questionnaires and documentation. Descriptive statistics with the help of excel 2016 are the technical analysis of the data used in this research. The results showed a mean score of 2.71 (67.93 per cent) with a high 
ranking. The results of this study show that learning motivation in class $X$ MIA MAN 4 Pekanbaru using Google Classroom media with the high-category.

Keywords: Learning, Learning Motivation, Google Classroom

\section{PENDAHULUAN}

Belajar adalah sesuatu hal yang sangat penting bagi anak dalam rangka mempersiapkan dirinya di masa depan. Menurut (Budiningsih, 2005). Berdasarkan teori behavioristik, belajar adalah perubahan tingkah laku sebagai akibat dari adanya interaksi antara stimulus dan respon. Cepat atau lambat setiap anak akan dituntut untuk menjadi pribadi yang mandiri di kemudian hari dengan perubahan tingkah laku menjadi lebih baik. Proses belajar dapat dilakukan kapanpun dan dimanapun. Namun, pada umumnya seorang anak akan dituntut untuk mengikuti proses belajar formal di sekolah. Dengan harapan, belajar di sekolah mampu membentuk karakter peserta didik menjadi lebih baik.

Adanya motivasi belajar yang datang dari guru dan minat belajar yang tinggi dari peserta didik itu sendiri dapat mempengaruhi meningkatnya prestasi belajar peserta didik. Prestasi belajar yang diperoleh peserta didik dipengaruhi oleh motivasi belajar yang tinggi, karena dengan tingginya motivasi belajar seorang peserta didik akan melakukan sesuatu hal yang diminati dan disenanginya. Dan begitu pula sebaliknya, tanpa adanya motivasi belajar yang tinggi maka peserta didik itu tidak akan melakukan suatu hal dengan senang hati atau bahkan melakukan sesuatu dengan terpaksa (Romlah., S., et. al, 2019).

Salah satu permasalahan dalam proses pembelajarannya yaitu motivasi belajar siswa yang rendah hal itu ditandai penyelesaian tugas dari guru yang ditunda-tunda selain itu siswa lebih senang dengan tugas - tugas yang sederhana, sedang kan motivasi siswa yang tinggi apabila siswa tekun menghadapi tugas. Mengenai pembelajaran daring melalui Google Classroom pada pembelajaran biologi ini pun mempunyai beberapa kendala, seperti sering terjadinya gangguan pada aplikasi, keterhambatnya jaringan internet yang dimiliki peserta didik serta kurang efektifnya, sehingga membuat motivasi yang dialami siswa dalam pembelajaran yang rendah, karna menggunakan Google Classroom dianggap pembelajaran yang kurang menarik dalam menimbulkan motivasi belajar siswa dibandingkan pembelajaran secara langsung di kelas. Menggunakan media pembelajaran Google Classroom berdampak terhadap pemicu tinggi ataupun rendahnya motivasi belajar para peserta didik. Sehingga menarik atau tidaknya pembelajaran yang diberikan oleh guru dapat menentukan dorongan peserta didik untuk lebih semangat dalam mengikuti pembelajaran. Apabila peserta didik merasa senang dan nyaman pada saat mengikuti pembelajaran menggunakan media Google Classroom yang guru berikan, maka motivasi dan semangat belajar para peserta didik akan meningkat. Begitu juga sebaliknya, apabila peserta didik tidak merasa nyaman dengan pembelajaran Google Classroom yang 
telah diterima maka peserta didik justru akan merasa cepat bosan dan hal tersebut dapat menjadi pemicu menurunnya semangat dan motivasi belajarnya.

\section{METODE PENELITIAN}

Penelitian ini merupakan penelitian survey menggunakan pendekatan kuantitatif dengan metode deskriptif. Penelitian Survei merupakan penelitian dengan mengumpulkan informasi suatu sampel dengan menanyakannya melalui angket untuk menggambarkan berbagai aspek dari populasi. (Arifin., Z., 2011). Survei dalam penelitian ini akan diterapkan dengan mengumpulkan informasi tentang pelaksanaan pendidikan karakter melalui pelajaran dengan menggunakan angket yang diisi oleh para responden yaitu para siswa X MIA MAN 4 Pekanbaru.

Populasi dalam pengertian yang lain yaitu wilayah generalisasi yang terdiri atas obyek/subyek yang mempunyai kualitas dan karakteristik tertentu yang ditetapkan oleh peneliti untuk dipelajari dan kemudian ditarik kesimpulannya (Sugiyono, 2010). Populasi dalam penelitian ini adalah seluruh siswa MAN 4 kelas X MIA Pekanbaru yang berjumlah 2 kelas, dengan jumlah populasi 50 siswa. Instrumen yang digunakan sebagai pengumpulan data adalah data angket persepsi siswa terdiri dari 4 indikator.

Analisis data menggunakan statistik deskriptif dengan bantuan Excel 2016. Analisis data menurut (Sugiyono, 2010) menjelaskan bahwa analisis data adalah proses mencari dan menyusun secara sistematis data yang diperoleh dari hasil uji angket, sehingga dapat mudah dipahami, dan temuannya dapat diinformasikan kepada orang lain.

Pengumpulan data penelitian dilakukan dengan penyebaran kuesioner. Jenis angket yang digunakan yaitu angket tertutup, karena angket sudah tersedia jawabannya sehingga responden hanya mengisi jawaban sesuai pendapatnya dengan memberi tanda centang $(\sqrt{ })$ pada salah satu pilihan jawaban.

\section{HASIL DAN PEMBAHASAN}

Data yang diperoleh dari penelitian ini didapatkan langsung dari 50 responden dengan cara penyebaran angket kepada responden melalui aplikasi WhatsApp

Data yang diperoleh peneliti dalam menganalisis persepsi siswa terhadap penggunaan media google classroom terdiri dari 4 indikator dengan 30 pernyataan. Indikator yang digunakan sebagai tolak ukur dalam persepsi siswa terhadap penggunaan media google classroom adalah Tekun menghadapi tugas, ulet menghadapi kesulitan, Menunjukkan minat terhadap macam-macam masalah, Senang bekerja mandiri, Dapat mempertahankan pendapat, Tidak mudah melepaskan hal yang diyakini, Senang Mencari Dan Memecahkan Masalah- Masalah Soal dan Cepat bosan pada tugas-tugas ruu.

Data hasil rekapitulasi angket persepsi siswa terhadap penggunaan media google classroom dapat dilihat pada tabel dibawah ini

Tabel 4.7. Rekapitulasi Hasil Angket Yang Menunjukkan Motivasi Belajar.

\begin{tabular}{|l|l|c|c|c|}
\hline No & Indikator & $\begin{array}{c}\text { Rerata } \\
\text { Skor }\end{array}$ & $\%$ & Kriteria \\
\hline
\end{tabular}




\begin{tabular}{|l|l|c|c|c|}
\hline 1 & Tekun menghadapi tugas & 2,85 & 71,4 & Tinggi \\
\hline 2 & Ulet menghadapi kesulitan & 2,52 & 63,16 & Tinggi \\
\hline 3 & $\begin{array}{l}\text { Menunjukkan minat terhadap macam- } \\
\text { macam masalah }\end{array}$ & 2,74 & 68,5 & Tinggi \\
\hline 4 & Senang bekerja mandiri & 2,56 & 64,0 & Tinggi \\
\hline 5 & Dapat mempertahankan pendapat & 2,68 & 67,12 & Tinggi \\
\hline 6 & $\begin{array}{l}\text { Tidak mudah melepas kan hal yang di } \\
\text { yakini }\end{array}$ & 2,98 & 74,5 & Tinggi \\
\hline 7 & $\begin{array}{l}\text { Senang mencari dan memecahkan } \\
\text { masalah- masalah soal }\end{array}$ & 2,47 & 61,83 & Tinggi \\
\hline 8 & $\begin{array}{l}\text { Cepat bosan pada tugas-tugas rutin } \\
\text { Rerata }\end{array}$ & 2,58 & 64,62 & Tinggi \\
\hline & \multicolumn{2}{|l|}{67,67} & Tinggi \\
\hline
\end{tabular}

Berdasarkan tabel diatas dapat dilihat bahwa rata-rata skor Rekapitulasi Hasil Angket Yang Menunjukkan Motivasi Belajar adalah 2,67 termasuk dalam kategori baik, dengan persentase $67,0 \%$.
Berikut adalah diagram skor dan presentase dari setiap indikator Motivasi Belajar siswa dalam pembelajaran menggunakan media google classroom dapat dilihat sebagai berikut:

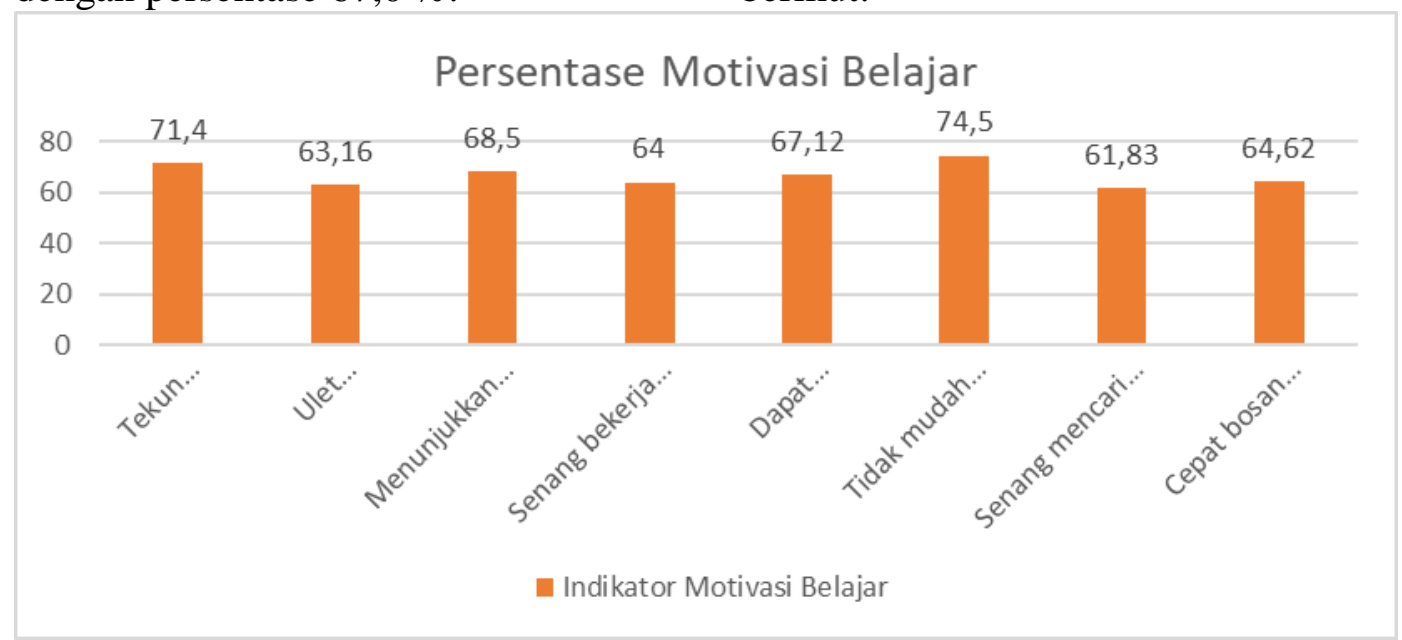

Gambar 4.1. Diagram Perolehan Skor dan Presentase Setiap Indikator Motivasi Belajar

Berdasarkan hasil data penelitian yang diperoleh pada indikator tentang tekun menghadapi tugas terdapat pada Tabel 3.9 dengan rerata 2,85 persentase $(71,4 \%)$ dengan Kategori Tinggi, artinya siswa bersungguhsungguh dalam menyelesaikan tugastugas yang diberikan guru, maka siswa tersebut akan tekun dalam mengerjakannya, meskipun tugas yang diberikan dalam jumlah banyak. Data ini menunjukkan bahwa siswa termotivasi dalam pembelajaran menggunakan media Google Classroom. Hal ini sejalan dengan hasil penelitian (Romlah et al. 2019). Bahwa motivasi belajar siswa SD Al Barokah 448 meningkat dengan menggunakan media ICT berbasis For VBA Excel pada garis bilang, 
menyatakan jika siswa tidak tekun dalam menghadapi tugas maka siswa akan terkendala dalam meraih prestasinya dan begitu sebaliknya. Untuk meraih prestasi selain rajin dan ulet dalam menghadapi tugas siswa juga harus tekun dalam belajar.

Pada indikator tentang ulet menghadapi kesulitan terdapat pada Tabel 4.0 dengan rerata 2,52 persentase $(63,16 \%)$ dengan Kategori Tinggi, artinya siswa tidak mudah putus asa yang disertai kemauan yang keras dalam berusaha mencapai tujuannya. Siswa memiliki keuletan yang tinggi dalam menghadapi kesulitan belajar hal ini dapat dibuktikan ketika ada soal biologi yang sulit siswa tetap berusaha untuk mengerjakannya dan siswa juga bisa menanyakan kepada teman kalau kesulitan menjawab soal, ini dikarenakan siswa sangat serius dalam proses pembelajaran sehingga mudah dalam menghadapi masalah pelajaran. Data ini menjukkan bahwa siswa termotivasi dalam pembelajaran menggunakan media Google Classroom, Hal ini sejalan dengan penelitian (Akbar., et. al, 2019) yang menunjukkan pada pembelajaran biologi siswa termotivasi dalam belajar, bahwa siswa yang ulet dalam menghadapi kesulitan dalam belajar akan memperoleh nilai yang baik. Siswa juga memerlukan kreativitas berpikir sehingga siswa mampu memecahkan masalahnya sendiri dan tidak terlalu tergantung kepada guru.

$$
\text { Pada indikator tentang }
$$
menunjukkan minat terhadap macammacam masalah terdapat pada Tabel 4.1 dengan rerata 2,74 persentase $(68,5$ $\%)$ dengan Kategori Tinggi. Artinya siswa harus mempunyai minat untuk belajar, supaya siswa dalam menghadapi proses pembelajaran tidak terganggu, hal ini dibuktikan siswa harus benar-benar mempersiapkan minat dari rumah untuk belajar, supaya dapat memperoleh nilai yang baik, seandainya siswa tidak mempunyai minat maka akan memperoleh nilai jelek. Data ini menjukkan bahwa siswa termotivasi dalam pembelajaran menggunakan media Google Classroom. Sejalan dengan penelitian Sur et. al (2020) yang menyatakan bahwa perkuliahan daring berpengaruh terhadap motivasi belajar mahasiswa selama masa pandemi, Terjadi peningkatan motivasi belajar mahasiswa melalui pelaksanaan perkuliahan online di masa pandemi Covid-19, yang menyatakan minat sangat berpengaruh terhadap aktivitas belajar siswa, oleh karena itu guru sangat berguna untuk membangkit kan minat siswa terhadap macam-macam masalah yang hadapi sehingga membuat siswa termotivasi dalam belajar siswa. Adanya motivasi yang tinggi dalam diri siswa akan menjadikan mereka berusaha memperoleh prestasi belajar setinggitingginya.

Pada indikator tentang senang bekerja mandiri terdapat pada Tabel 4.2 dengan rerata 2,56 persentase $(64,0$ $\%)$ dengan Kategori Tinggi. Artinya siswa memiliki rasa tanggung jawab terhadap tugasnya dan mampu dan mampu mengerjakan tugas tanpa bantuan orang lain, siswa tidak memiliki kebiasaan belajar sendiri, karena siswa tidak pernah belajar saat di rumah. Data ini menjukkan bahwa siswa termotivasi dalam pembelajaran menggunakan media Google Classroom. Hal ini sejalan dengan penelitian (Nasrah \& A. Mufiah. 2020), yang menyatakan siswa 
termotivasi dalam belajar menggunakan pembelajaran daring, bahwa siswa memiliki kebiasaan belajar mandiri, karena siswa pernah mengulang kembali pelajaran yang disampaikan oleh guru di rumah. Siswa akan belajar mandiri ketika akan dilakukannya tes atau ujian.

Pada indikator tentang dapat mempertahankan pendapat terdapat pada Tabel 4.3 dengan rerata 2,68 persentase $(67,12 \%)$ dengan Kategori Tinggi. Artinya siswa dapat dan berani memepertahankan pendapatnya, jika siswa tidak aktif dalam pembelajaran akan menyebabkan siswa sulit dalam mempertahankan pendapatnya. Data ini menjukkan bahwa siswa termotivasi dalam pembelajaran menggunakan media Google Classroom. Sejalan dengan penelitian (Triyaswati \& Nafiah, 2020) yang menunjukkan penggunakan media aplikasi zoom pada setiap kegiatan belajar dapat meningkatkan motivasi belajar siswa, bahwa siswa yang berpartisipasi aktif dan kreatif berpendapat untuk membangun pikiran mereka dalam pembelajaran akan mempunyai wawasan yang luas. Jika siswa tidak aktif dalam pembelajaran akan menyebabkan siswa sulit dalam mempertahankan pendapatnya.

Pada indikator tentang tidak mudah melepas hal yang diyakini terdapat pada Tabel 4.4 dengan rerata 2,98 persentase $(74,5 \%)$ dengan Kategori Tinggi. Artinya siswa percaya terhadap apa yang di kerjakannya atau teguh pendirian. Data ini menjukkan bahwa siswa termotivasi dalam pembelajaran menggunakan media Google Classroom. Sejalan dengan penelitian Oktaviani \& Dewi (2020) yang menyatakan bahwa penggunan media VBA For Excel pada pembelajaran pecahan mendapat respon positif artinya motivasi belajar siswa dalam kategori tinggi, menyatakan siswa yang belajar kreatif akan meningkatkan keyakinan siswa tersebut, sehingga siswa tidak mudah akan terpengaruh dengan teman lainnya dan guru harus mampu untuk membaca situasi dan memonitor serta mengevaluasi peristiwa-peristiwa serta sanggup memberi resiko untuk melakukan inovasi terhdap siswa.

Pada indikator tentang senang mencari dan memecahkan masalahmasalah soal terdapat pada Tabel 4.5 dengan rerata 2,47 persentase $(61,83$ $\%)$ dengan Kategori Tinggi, berarti menunjukan kurang kepercayaan diri siswa itu sangat luar biasa dengan pembelajaran menggunakan media Google Classroom. Artinya siswa kurang senang mencari dan memecahkan maslah-masalah soal dan menyukai tantangan. Data ini menjukkan bahwa siswa termotivasi dalam pembelajaran menggunakan media Google Classroom. Sejalan dengan penelitian (Barus, 2019) yang menyimpulkan bahwa motivasi belajar mahasiswa pada mata kuliah atletik lanjut program studi olahraga univeritas quality brastagi terdapat motivasi belajar siswa dalam menggunakan media Google Classroom di kategorikan tinggi, menyatakan setiap siswa ingin mengetahui hasil evaluasinya supaya mengetahui kemampuan yang dilakunya untuk memecahkan masalah yang dihadapi siswa.

Pada indikator tentang cepat bosan pada tugas-tugas rutin terdapat pada Tabel 4.6 dengan rerata 2,58 persentase $(64,62 \%)$ dengan Kategori 
Tinggi. Artinya siswa akan cepat bosan dengan hal-hal yang bersifat berulang-ulang begitu saja sehingga kurang efektif. Data ini menjukkan bahwa siswa termotivasi dalam pembelajaran menggunakan media Google Classroom. Sejalan dengan penelitian (Melisari et. al, 2018) menyatakan bahwa menggunakan aplikasi VBA For Ecxel siswa dapat termotivasi belajar dalam pembelajaran matematika pada materi KPK dan FPB, menyatakan dalam proses pembelajaran guru terlebih dahulu seperti penyususnan pengembangan silabus dan rencana pelaksanan pembelajaran dan guru tidak terpaku dengan mengunakan satu metode saja, sebaiknya guru menggunakan metode yang bervariasi, agar siswa tidak membosankan, tetapi menarik perhatian siswa untuk belajar.

Dari hasil rekapitulasi 8 indikator dengan skor rerata 2,67 persentase $(67,0 \%)$ dengan Kategori Tinggi. Berdasarkan data tersebut, dapat diketahui bahwasanya siswa kelas $\mathrm{X}$ MIA MAN 4 Pekanbaru termotivasi dalam belajar pada mata pelajaran biologi menggunakan media Google Classroom. Hal ini menunjukkan bahwa kemajuan teknologi seperti sekarang ini dapat memberikan dampak terhadap belajar siswa seperti yang terdapat dalam penelitian ini bahwa tidak mudah melepaskan hal yang diyakini memberi pengaruh besar terhadap motivasi individu siswa yang berdampak terhadap motivasi belajar siswa sehingga berpengaruh pada keberhasilan belajar.

\section{KESIMPULAN}

Kesimpulan dari penelitian ini yaitu ditemukan indikator Tidak mudah melepaskan hal yang diyakini dengan skor rerata 2,98 (74,5\%) dengan Kategori Tinggi, karna siswa percaya terhadap apa yang di kerjakannya atau teguh pendirian, hal ini yang membuat siswa termotivasi dalam belajar. Sedangkan pada indikator Senang mencari dan memecahkan masalah - masalah soal dengan rerata 2,47 persentase $(61,83 \%)$ dengan Kategori Tinggi, dikatakan indikator dengan nilai terendah dari keseluruhan indikator, karena siswa kurang bisa memecahkan masalah-masalah soal yang siswa hadapi, sehingga siswa tersebut membutuhkan seseorang memberikan dorongan untuk memecahkan masalah. Maka hasil penelitian dari keseluruhan 8 indikator dengan rerata 2,67 persentase $(67,0 \%)$ dengan Kategori Tinggi. Dengan adanya motivasi belajar siswa dalam pembelajaran biologi menggunakan media Google Classroom pada kelas X MIA MAN 4 Pekanbaru, motivasi belajar yang datang dari guru dan belajar yang tinggi dari peserta didik itu sendiri dapat mempengaruhi meningkatnya prestasi belajar peserta didik. Ditemukan juga bahwa motivasi belajar siswa kelas X MIA MAN 4 Pekanbaru dalam pembelajaran menggunakan media Google Classroom dalam Kategori Tinggi.

\section{DAFTAR PUSTAKA}

Arifin, Z. 2011. Penelitian Pendidikan Metode dan Pradigma Baru. Remaja Rosdakarya.Bandung.

Arikunto, S. 2011. Prosedur Penelitian Suatu Pendekatan Praktik. Edited By Rineka Cipta. (Edisi Revisi). Jakarta.

Budiningsih, A. 2005. Belajar dan 
Pembelajaran. Rineka Cipta: Jakarta.

Ishak, S. 2015. Metode Pembelajaran Sains Dalam Perspektif Pendidikan Islam. Cahaya Anugrah.Jakarta

Melisari., Asri, S., \& Siti, C., 2019. Analisis Motivasi Belajar Siswa Menggunakan Aplikasi Visual Basic Excel Pada Materi KPK Dan FPB. Jurnal Pengabdian. 02 (01): 82-87.

Nasution., 2015. Berbagai Pendekatan dalam Proses Pembelajaran Mengajar. Jakarta: Bumi Aksara.

Oktaviani, R., \& Puspita, D.D., 2020. Analisis Motivasi Belajar Siswa SMPN 8 Cimahi Menggunakan Media Visual Basic for Application Berbasis Microsoft Excel pada Materi Pecahan. 3 (2): 133-140.

Romlah, S., Nurlela, N., Siti, N., \& Wahyu, S., 2019. Analisis Motivasi Belajar Siswa Sd Albarokah 448 Bandung Dengan Menggunakan Media Ict Berbasis For Vba Excel Pada Materi Garis Bilangan. Jurnal Pendidikan Matematika. 3 (1):
$220-26$.

Sardiman., 2011. Interaksi Dan Motivasi Belajar Mengajar. Edited By Raja Grafindo Persada. Jakarta.

Slameto., 2010. Belajar dan FaktorFaktor yang Mempengaruhinya. Rineka Cipta: Jakarta.

Sudjana, N., 2013. Dasar- Dasar Proses Belajar Mengajar. Remaja Sinar Baru Aglesindo: Bandung.

Sugiyono. 2010. Metode Penelitian Pendidikan. Edited By Remaja Rosdakarya. Bandung.

Triyaswati, D., \& Nafiah., 2019. Peningkatan Motivasi Belajar Siswa Menggunakan Aplikasi Zoom Pada Siswa Kelas 4 SD Negeri 1 Cepokomulyo Malang. Jurnal Pendidikan. 2 (1): 20-26.

Tika, \& H. Moh, P., 2005. Metode Penelitian Geografi. Karyaabdi. Jakarta

Uno, H.B. 2008. Teori Motivasi Dan Pengukurannya. Edited By Bumi Aksara. Jakarta. 